Marta Rakoczy

marta.rakoczy@wp.pl

\title{
Słowo magiczne jako działanie - o kilku walorach koncepcji Bronisława Malinowskiego
}

\begin{abstract}
Rakoczy Marta, Stowo magiczne jako działanie - o kilku walorach koncepcji Bronistawa Malinowskiego (Magical Word as an Action. A Few Thoughts about Bronisław Malinowski’s Concepts). „Poznańskie Studia Slawistyczne” 4. Poznań 2013. Adam Mickiewicz University Press, pp. 151-163. ISBN 978-83-232-2525-6. ISSN 2084-3011.

This article concerns Bronisław Malinowski's ethnographical theory of magical word. His theory was a revolutionary one for two reasons (1) he claimed that magical word is not an instrument of understanding of ,primitive mentality” (2) he argued that analysis of magical word demanded abandoning of textual bias which entailed our seeing linguistic genres as semantically autonomous texts. Malinowski was not so interested in the question of literacy. $\mathrm{He}$ remarked, though, that writing determinated our linguistic reflection and that magical word, as another oral linguistic genres, demanded a radical rejection of textual conceptions of meaning, language and folklore. Although Malinowski's methodological stipulations were not always consistent and his rejection of textual bias was fairly half, his abandonment of the conception of „magical world view” which is a foundation for uses of magic is still up-to-date.
\end{abstract}

Keywords: magical word, literacy, textual bias, textualisation, ,magical world view”

Magia jako instytucja kulturowa była od chwili narodzin antropologii jednym $\mathrm{z}$ jej podstawowych zagadnień ${ }^{1}$. Antropologiczne teorie magii można podzielić na dwie kategorie. Teorie mentalistyczne przyjmują, że magia ma charakter poznawczy i co więcej, że jest ona dla antropologa narzędziem wglądu w swoisty dla „umysłowości pierwotnej” światopogląd

${ }^{1}$ Cf. M. Buchowski, Magia i rytuat, Warszawa 1993 oraz idem, Racjonalność, translacja, interpretacja. O badaniu myślenia magicznego $w$ antropologii i filozofii brytyjskiej, Poznań 1990. 
nieredukowalny do poznania naukowego. Teorie antymentalistyczne twierdzą, że podstawową funkcją magii nie jest funkcja poznawcza, magia jest bowiem techniką oddziaływania na rzeczywistość, a nie jej wyjaśniania. W konsekwencji, słowo magiczne nie jest narzędziem myśli i dlatego nie może stać się ono instrumentem antropologicznego wglądu w „umysłowość pierwotną". Do wielkich patronów mentalistycznych teorii magii zaliczyć można Jamesa Frazera, Luciena Lévy-Bruhla, Claude'a Lévi-Straussa, a współcześnie - Stanleya J. Tambiaha. Głównym patronem antymentalistycznej koncepcji magii oraz słowa magicznego pozostaje Bronisław Malinowski. Artykuł ten będzie poświęcony stworzonej przez autora Argonautów Zachodniego Pacyfiku koncepcji słowa magicznego, a dokładnie dwóm zagadnieniom: (1) innowacji, jaką wniósł Malinowski do badań nad magicznymi praktykami językowymi oraz (2) problemom, na które natknął się w badaniu tychże praktyk oraz temu, jak problemy te mogą być instruktywne dla dzisiejszych badań słowa magicznego.

Kiedy pojechałem tam po raz pierwszy, wiedziałem, że dobry etnograf musi kolekcjonować „folklor”. Gdy byłem już w stanie posługiwać się miejscowym językiem, skrzętnie zapisywałem wszystkie opowieści przekazywane mi przez tubylców. Zbierałem opowiadania o wilkołakach i latających czółnach, o złośliwych macochach i odważnych żeglarzach, o początkach magii i dziwnych wybrykach skąpych nierządnic. Stopniowo jednak uświadamiałem sobie, że sami tubylcy zdają sobie sprawę z istoty przedstawienia, której ciągle nie mogłem uchwycić; zbierałem bowiem teksty, ale brak było kontekstów. Z biegiem czasu stwierdziłem, że sposób, w jaki opowieść jest przekazywana i przyjmowana przez słuchaczy, okoliczności, w jakich się to odbywa, a także bezpośrednie i pośrednie konsekwencje takiego opowiadania są prawie tak samo ważne jak sam tekst. Brakowało mi tylko kontekstu sytuacji, ale często również kontekstu dawnych informacji i komentarzy, których mogliby udzielić tubylcy. Po opowiadaniu mi jakiejś ważnej czy uświęconej historii narrator często kontynuował opowieść, mówiąc coś, co wydawało mi się wyłącznie przejawem jego gadatliwości. (...) W trakcie badań wykryłem, że tego rodzaju epilogi czy dodatki do narracji bardzo często pozwalają na nowe i nieoczekiwane spojrzenia na rytuał, pozycję i przywileje społeczności, klanów i jednostek oraz na sposób, w jaki w miejscowych wierzeniach została ustalona wartość magii ${ }^{2}$.

${ }^{2}$ B. Malinowski, Podstawy wiary i moralności, przeł. B. Leś, w: idem, Dzieła, t. 7, Mit, magia, religia, Warszawa 1990, s. 472-474. 
Nie ma chyba lepszego fragmentu ukazującego przepaść między doświadczeniem językowym antropologa wychowanego w kulturze pisma a doświadczeniem uczestnika kultury oralnej. Pierwszy zbiera zamknięte semantycznie świadectwa - teksty rozumiane jako przedmioty kolekcji antropologicznej, a w słowie mówionym skłonny jest widzieć „gadanie” pozbawione celu, pełne redundancji i przesady. Drugi traktuje słowo jako żywotną siłę przenikającą rzeczywistość, powiązaną z wieloma działaniami językowymi oraz pozajęzykowymi, widząc $w$ nich rzeczywistą moc, opatrzoną celem i znaczeniem. Właśnie tę przepaść zrozumiał Bronisław Malinowski i starał się ją pokonać. Rezultatem tych staran była etnograficzna koncepcja słowa, składająca się raczej z postulatów niż z twardych rozstrzygnięć teoretycznych. Nie proponowała ona gotowej metodologii. Jednak postulując porzucenie kategorii tekstu i koncentrację na skontekstualizowanym przestrzennie, czasowo i cieleśnie performance, antycypowała teorię aktów mowy sformułowaną przez Johna L. Austina i rozwijaną przez Johna R. Searle'a ${ }^{4}$, a także dokonany w latach dziewięćdziesiątych zwrot $\mathrm{w}$ badaniach nad folklorem, $w$ tym nad specyfiką słowa magicznego ${ }^{5}$. Choć zawierała przesłanki teoretyczne pozwalające na zastosowanie jej do badania wszelkich praktyk językowych, źródłowo miała służyć przede wszystkim badaniu praktyk pierwotnie oralnych.

Jak wiadomo, formuły magiczne - nie będące ,ani fragmentem konwersacji, ani modlitwą, twierdzeniem czy też środkiem porozumiewania się" - miały kluczowe znaczenie dla ukonstytuowania etnograficznej koncepcji słowa, bowiem to próba ich analizy była dla Malinowskiego impulsem do stworzenia nowych narzędzi teoretycznych. Polemizując z Lévy-Bruhlem, autor Etnograficznej teorii języka przyjął, że słowo magii nie

\footnotetext{
${ }^{3}$ Cf. G. Godlewski, Z Syriusza na Ziemie, na szorstki grunt, w: idem, Stowo - pismo sztuka stowa. Perspektywy antropologiczne, Warszawa 2008, s. 104-119.

${ }^{4}$ Cf. J.L. Austin, Jak działać stowami, w: idem, Mówienie i poznawanie. Rozprawy i wykłady filozoficzne, przeł. B. Chwedeńczuk, Warszawa 1993 oraz J.R. Searle, Czynności mowy: rozważania z filozofii języka, przeł. B. Chwedeńczuk, Warszawa 1987.

5 Cf. W. Bascom, Malinowski's Contribution to the Study of Folklor, „Folklor” nr 2, 1983, s. 163-172. Cf. M. Buchowski, Magia i rytuat oraz idem, Racjonalność, translacja, interpretacja...

${ }^{6}$ B. Malinowski, Etnograficzna teoria słowa magicznego, przeł. B. Leś, w: idem, Dzieta, t. 5, Ogrody koralowe i ich magia. Studium metod uprawy ziemi oraz obrzędów towarzyszacych rolnictwu na Wyspach Trobrianda, red. A.K. Paluch, Warszawa 1987, s. 348.
} 
jest efektem określonej organizacji umysłu pierwotnego ${ }^{7}$. Nie jest ono w ogóle narzędziem myśli; nie służy opisowi rzeczywistości, ani też przekazaniu jakichkolwiek informacji. Jest „narzędziem władzy”, bowiem „rola słów polega tu na działaniu, a nie na uczeniu się ich”. Ponieważ „pytania o znaczenie zaklęć i obrzędów magicznych" wydaje się krajowcom dziwną praktyką językowa, „nie jest łatwo wyjaśnić jakąś formułę czy uzyskać właściwy komentarz". Nie dlatego, że brak im odpowiednich możliwości intelektualnych. Jak zauważał Malinowski, ,jest kilku tubylców, którzy próbowali dotrzeć do źródeł magicznego słownictwa" ${ }^{8}$. Pytanie o znaczenie formuł magicznych świadczy po prostu o niezrozumieniu ich specyfiki; o przyłożeniu do nich nieadekwatnych narzędzi interpretacyjnych.

Opierając się na analizie zaklęć, Malinowski uznał, że zrozumienie wypowiedzi Trobriandczyków wymaga nie tylko znajomości słownika i gramatyki, ale też zrozumienia swoistego dla nich kontekstu sytuacyjnego i kulturowego, z którym są one powiązane - zrozumienia związku między działaniami językowymi a pozajęzykową aktywnością krajowców. Dotychczasowe teorie znaczenia, skoncentrowane na analizie mechanizmu odniesienia przedmiotowego, okazały się bezużyteczne do opisu słowa magicznego. ,Jeśli tłumacz - pisał Malinowski - stosowałby zwyczajne kryteria gramatyki, logiki i zgodności w odniesieniu do języka magii trobriandzkiej, nie poradziłby sobie z jej interpretacją". Krótko mówiąc, ani ówczesne językoznawstwo, ani ówczesna filozofia języka nie potrafiły, jego zdaniem, udzielić odpowiedzi na pytanie: w jaki sposób słowo magii znaczy i w jaki sposób może być ono przedmiotem interpretacji antropologicznej?

W myśl postulatów postawionych w Problemie znaczenia w językach pierwotnych, Etnograficznej teorii języka oraz w Etnograficznej teorii stowa magicznego znaczenie formuł magicznych można zrekonstruować tylko w odniesieniu do całego kontekstu kultury pierwotnej, w której magia jest jedną z najważniejszych instytucji. Właśnie dlatego materiał lingwistyczny miał być pozbawiony autonomii i umieszczony w tekście etno-

\footnotetext{
${ }^{7}$ Idem, Nauka i religia, przeł. B. Leś, w: idem, Dzieła, t. 7, s. 451.

${ }^{8}$ Idem, Argonauci Zachodniego Pacyfiku: relacje o poczynaniach i przygodach krajowców z Nowej Gwinei, przeł. B. Olszewska-Dyoniziak, S. Szynkiewicz, Warszawa 1987, s. 351.

${ }^{9}$ Idem, Etnograficzna teoria stowa magicznego, s. 354.
} 
graficznym. Zerwanie $\mathrm{z}$,prezentacją języka nie w formie słownik plus gramatyka, plus zestaw tekstów z adnotacjami" i położenie nacisku na „prezentację materiałów w formie ciąłłego opowiadania" ${ }^{10}$ było metodą nowatorską. Malinowski, pisząc o swojej ,niekonwencjonalnej metodzie traktowania formuł magicznych", chętnie to podkreślat ${ }^{11}$. Opis miał tu polegać na przedstawieniu przypisanej danemu informatorowi wypowiedzi: opowiadania, mitu, zaklęcia. Badacz zdawał sobie sprawę, że jakakolwiek piśmienna reprezentacja praktyk językowych, nawet jeśli zawiera opis towarzyszących im działań, jest niewystarczająca dla ukazania specyfiki oralnych sposobów posługiwania się słowem. Lingwistyce - zaznaczał - brakuje takiego pojęcia kontekstu, który „,by obejmował (...) nie tylko wypowiadane słowa, ale także wyraz twarzy, gesty, ruchy ciała, cała grupe ludzi obecnych przy wymianie wypowiedzi oraz część środowiska, w którym się ci ludzie znajdują" 12 . Nic dziwnego, że pokładał on nadzieje w filmie dźwiękowym, który mógłby wydobyć się z ograniczeń piśmiennej reprezentacji tego, co pismu obce ${ }^{13}$. Gramatyka i słownik nie wystarczały, aby ujrzeć społeczne reguły rządzące określonym użyciem słowa. Tylko badanie pragmatyki językowej - użycia słów skontekstualizowanych przestrzennie i czasowo - pozwalało, jego zdaniem, dostrzec, że język magii jest swoistym użyciem słowa.

Kłopot w tym, że autor Etnograficznej teorii języka nie był szczególnie konsekwentny. Nie zawsze rozpatrywał praktyki językowe w kontekście sytuacyjnym i kulturowym. Owszem, starał się przestrzegać postulatu wiązania ich interpretacji z interpretacją kultury, zaś słowa z kontekstem sytuacyjnym i kulturowym jego wypowiedzenia. Dlatego zarówno w Argonautach Zachodniego Pacyfiku, jak i w Życiu seksualnym dzikich znaczenie zaklęcia miało być rekonstruowane poprzez odniesienie do pragmatyki, a nie do semantyki języka; wszelkie zaklęcia pojawiały się w kontekście opisu działań pozajęzykowych krajowców, a słowom czarownika towarzyszyła rekonstrukcja towarzyszących im działań magicznych. W tym samym dziele jednak Malinowski, wskazując na to, co pomogło mu zinter-

\footnotetext{
${ }^{10}$ Idem, Etnograficzna teoria języka $i$ pewne wnioski praktyczne, przeł. B. Leś, w: idem, Dzieła, t. 5, Ogrody koralowe i ich magia, cz. 2: Język magii i ogrodnictwa, s. 22.

${ }^{11}$ B. Malinowski, Etnograficzna teoria stowa magicznego, s. 397.

${ }^{12}$ Idem, Etnograficzna teoria języka..., s. 55.

${ }^{13}$ Ibidem, s. 62.
} 
pretować dane zaklęcie, nie powoływał się na kontekst, lecz na obecne w nim ,słownictwo" ${ }^{14}$.

W Ogrodach koralowych i ich magii główny korpus zaklęć kiriwińskich został skrzętnie odseparowany od opisu antropologicznego. Zawarte w nim świadectwa językowe zostały, co prawda, opatrzone składającym się z dwóch części komentarzem. Choć pierwsza część stanowiąca komentarz ogólny miała uzupełniać daną formułę o kontekst socjologiczny, rytualny, strukturę, kontekst dogmatyczny oraz sposób recytacji, to druga - pozostawała tradycyjnym komentarzem lingwistycznym: analizą leksykograficzną i gramatyczną. Praktyka oddzielania formuł magicznych od opisu ich kontekstu sytuacyjnego i pozajęzykowego towarzyszyła Malinowskiemu nie tylko $w$ przygotowywaniu własnych publikacji, ale także w trakcie sporządzania notatek terenowych. Malinowski bardzo często zbierał i zapisywał formuły magiczne na osobnych kartkach notesu, oddzielając je od zapisu obserwacji tego, co się dzieje w trobriandzkiej wiosce. A tym samym traktował je jako osobne, autonomiczne teksty: przedmioty antropologicznej kolekcji porównywalne do zbieranych przez siebie trobriandzkich wzorów dekoracyjnych. Dokonywana poprzez sam fakt zapisu tekstualizacja folkloru - proces, który nakazywał widzieć w słowie magicznym ustabilizowany korpus stałych formuł, zniekształcał, rzecz jasna, rozumienie specyfiki przedpiśmiennych praktyk językowych. Uniemożliwiał dostrzeżenie, że folklor oralny cechuje twórczość i swobodna wariantowość, nie zaś sztywny, repetytywny kanon odtwarzanych mechanicznie formuł. Dostrzeżenie zniekształcenia, jakie wnosi sam fakt zapisu, a w rezultacie odkrycie wariantowości folkloru oralnego i konsekwencji, jakie ma ona dla teorii antropologicznych, dokonało się później dzięki, między innymi, takim badaczom, jak Paul Zumthor i Jack Goody, którzy dostrzegli, że „teksty” folkloru nie istnieją; nie istnieją ich kanoniczne i niekanoniczne wersje. Tym, co istnieje, są różne wykonania, te zaś nie dają się sprowadzić, na strukturalistyczną modłę, do jednego, semantycznego mianownika ${ }^{15}$.

Powróćmy do Malinowskiego. Wbrew radykalnym postulatom teoretycznym nie zrezygnował on całkowicie z narzędzi językoznawczych.

${ }^{14}$ B. Malinowski, Argonauci Zachodniego Pacyfiku..., s. 290.

${ }^{15}$ P. Zumthor, Introduction a la poesie orale, Paris 1983; J. Goody, Myth, Ritual and the Oral, Cambridge 2010. 
W Ogrodach koralowych Malinowski deklarował, że ,przynajmniej niektóre” z jego rozpoznań „okażą się z czasem wartościowe i pomocne w pracy innych kolekcjonerów i interpretatorów zaklęć magicznych" ${ }^{\text {"16. }}$. Dopuszczał zatem fakt, że słowo magiczne może znaczyć poza kontekstem jego wypowiedzenia; że może ono istnieć „,na papierze” - jako antropologiczne świadectwo. Ponadto, wbrew swoim postulatom, by odrzucić technikę translacji „słowo za słowo" sugerująca, że przekład jest procesem niewymagającym odniesienia do kontekstu sytuacyjnego i kulturowego, sam się nią posługiwał. A powołując się na zasadę relatywności symboli, chętnie używał kategorii gramatycznych zbudowanych na podstawie języków europejskich - kategorii traktowanych jako uniwersalne narzędzia opisu $^{17}$.

Etnograficzna teoria słowa magicznego i towarzyszący jej corpus inscriptiones kiriwiniensis pozostawiała wiele pytań bez odpowiedzi. Malinowski podkreślał, że dla Trobriandczyka słowo magii „działa”, nie zaś „znaczy”, zaś dla antropologa „znaczy” ono, a nie „działa”. Właśnie dlatego usiłował zrozumieć semantykę rządzącą zaklęciami magicznymi. W Argonautach Zachodniego Pacyfiku pisał o zawartych w nich ,niejasnych aluzjach mitologicznych”, ,opisach efektów”, jakie magia ma wywrzeć na dany element rzeczywistości kulturowej, ,przesadzie i metaforach” mających akcentować potęgę zaklęcia ${ }^{18}$, a także o tym, że niektóre zaklęcia, stanowiąc „odbicie tubylczych wierzeń" ${ }^{19}$, mogą być pomocne w ich bada$\mathrm{niu}^{20}$. Tym tropem interpretacyjnym zmierzał też w Życiu seksualnym dzikich. Analizując semantykę formuły magii upiększającej wykonywanej nad strojem kobiety ciężarnej, pisał, że „na samym początku wzywa się ptaka o pięknym kształcie i lśniąco białym upierzeniu, którego nazwa w głównej części formuły działa jak najpotężniejszy urok. Kojarząc się z nazwami zatoki oraz dołów na wodę, jednym słowem miejsc, w których brzemienna kobieta myje się i kappie, ma ona zdolność uczynienia jej cery bielszą,21.

${ }^{16}$ B. Malinowski, Etnograficzna teoria stowa magicznego, s. 397.

${ }^{17}$ Cf. W.J. Burszta, Język w myśli etnologicznej, Wrocław 1986, s. 69.

${ }^{18}$ B. Malinowski, Argonauci Zachodniego Pacyfiku..., s. 270-271.

${ }^{19}$ Ibidem, s. 336.

${ }^{20}$ Ibidem, s. 335.

${ }^{21}$ B. Malinowski, Życie seksualne dzikich w pótnocno-zachodniej Melanezji, Warszawa 1957, s. 319. 
Jeśli w Etnograficznej teorii języka Malinowski, chcąc ukazać pragmatyczny charakter wszelkich praktyk językowych, utożsamił znaczenie wypowiedzi z jej skutkiem dostępnym empirycznie, to w świetle Etnograficznej teorii stowa magicznego okazało się, że propozycja ta w odniesieniu do formuł magicznych nie jest wystarczająca. Jeśli skutek miał być dany empirycznie, to zaklęcie pozostawało dla etnografa bez znaczenia. Krótko mówiąc, koncepcja słowa magicznego jako „czystego” działania była w odniesieniu do formuł magicznych nieadekwatna. Można było przyjąć, że jeśli dla krajowców magia nie tylko działa, ale także znaczy, to dla antropologa ani nie znaczy, ani też nie działa. Malinowski natknął się tu na problem fundamentalny, zaś jego wyjaśnienia przypominały raczej próbę obejścia go niż rozwiązania. „Dla etnografa - pisał - słowa magii mają (...) inne znaczenie, nawet bardziej istotne niż ich skutek mistyczny, mianowicie znaczenie, jakie słowa magii mają dla istot ludzkich. W tym miejscu etnograf musi wyjść poza to, o czym tubylcy są w stanie go poinformować. Nie tylko musi przebadać wszystkie możliwe skojarzenia, ale również potraktować fragmenty tekstów magicznych jako dowody socjologiczne, inne fragmenty jako formy sugestii, jeszcze inne jako środki wyrażania nadziei i pragnień" ${ }^{22}$. Usiłując sformułować fenomen znaczenia formuły magicznej - zwłaszcza sposobu, w jaki może być ona istotna dla antropologa, Malinowski wskazywał, że jej znaczenie jest niejako wielopoziomowe. Polega ono na: „skutku, jaki zgodnie z wierzeniem wywołuje”, ,sposobie, w jaki jest traktowane w kontekście rytualnym i ogólnokulturowym", ,jego etymologicznych powiązaniach, które wykazują wpływ, jaki wywiera ono na umysł czarownika i każdego członka społeczności” oraz „różnych funkcjach socjologicznych tego słowa” ${ }^{23}$. Była to próba systematyzacji problematyki; systematyzacji jednak wstępnej, nigdy nierozwiniętej i o tyle wątpliwej, że prowadzącej do wniosku, że pełne znaczenie formuł magicznych jest dane jedynie antropologowi, który w przeciwieństwie do krajowców „wie”, co słowa zaklęcia „naprawdę” znaczą.

Jedno jednak jest pewne. W trakcie swoich badań Malinowski zaczął przeczuwać, że pismo - jako narzędzie antropologicznej reprezentacji rzeczywistości badanej - jest nieadekwatnym narzędziem dokumentacji

\footnotetext{
${ }^{22}$ Idem, Etnograficzna teoria stowa magicznego, s. 394.

${ }^{23}$ Ibidem, s. 395.
} 
i analizy doświadczenia terenowego. Pismo bowiem nie jest zapisem mowy; jej wierną reprezentacją. Jest ono medium, które zgodnie z późniejszymi rozpoznaniami takich teoretyków piśmienności, jak Walter J. Ong, Marshall McLuhan, Jack Goody i Eric A. Havelock wpływa na sposób postrzegania zarówno języka, jak i kultury jako takiej. Pismo wnosi nową organizację doświadczenia, odmienną od tej, jaką dysponują kultury pierwotnie oralne. Tym samym tworzy ono swoistą epistemologię, wyraźnie warunkująca poznanie antropologiczne i mogącą zniekształcać nasze rozumienie magii.

Zarysowana przez Malinowskiego w Problemie znaczenia w językach pierwotnych i w Etnograficznej teorii języka koncepcja słowa jako działania była zatem osiagnięciem rewolucyjnym. Pozwalała bowiem zrelatywizować zachodnią refleksję nad językiem, wskazując na jej uwarunkowania medialne i instytucjonalne. Malinowski zauważył, że użycie pisma charakterystyczne dla dyskursu naukowego sprawia, że widzimy w języku wyłącznie narzędzie myśli o funkcji referencyjnej ${ }^{24}$. To pismo, utrwalając, a tym samym izolując wypowiedź od kontekstu jej wypowiedzenia, tworzy ideę ,dyskursu autonomicznego”, który znaczy poza kontekstem sytuacyjnym i kulturowym jego wypowiedzenia. To pismo, materializując wypowiedź na powierzchni dostępnej analitycznej władzy oka, rodzi poczucie przepaści ontologicznej dzielącej język, umysł i rzeczywistość, a w konsekwencji, prowadzi do idei języka jako osobnej domeny przedmiotowej, odseparowanej od kontekstu jego użycia oraz do idei myślenia jako czegoś nie tylko odrębnego, ale też uprzedniego wobec pozostałych działań. W końcu pismo, tworząc swoiste kanony racjonalności, skłania do postrzegania różnorodnych zachowań kulturowych jako podyktowanych zorganizowanym systemem wierzeń - jednorodnym obrazem świata zawartym, między innymi, w słowie magicznym i determinującym sposób myślenia jego użytkowników.

Malinowski zauważał, że słownictwo stosowane w formułach magicznych „wiąże się ściśle z bardzo złożonym systemem dogmatów, z założeniami teoretycznymi odnoszącymi się do pierwotnej, mistycznej siły zawartej w słowach, do mitów, niewidocznego współdziałania duchów

${ }^{24}$ B. Malinowski, Problem znaczenia $w$ jezzkach pierwotnych, przeł. J. Szymura, w: idem, Dzieła, t. 8, Jednostka, spoteczność, kultura, red. A.K. Paluch, Warszawa 2000, s. $338-339$. 
przodków, a co najważniejsze, do oddziaływania na zasadzie sympatycznego powinowactwa zwierząt, sił przyrody i przedmiotów" ${ }^{25}$. Jednocześnie jednak wyraźnie podkreślał, że za słowem magicznym i stojącym za nim „systemem określonych zabiegów lingwistycznych” związanym ze „stosowaniem metafor, przeciwieństw, powtórzeń, porównań przez negację poleceń i pytań z odpowiedzią" - nie stoi ,jakakolwiek wyraźna doktryna"26. Nie znaczy to, że słowu magicznemu brak precyzji. Znaczy to, że pytanie o analityczną precyzję wypowiedzi świadczy o niezrozumieniu funkcji, jaką w kulturze krajowców pełni język magii. Według Malinowskiego za słowem magicznym nie stoi jakikolwiek ,,magiczny obraz świata”, określany przez Luciena Lévy-Bruhla mianem ,mistycznych wyobrażeń zbiorowych" ${ }^{\text {27 }}$. Postrzeganie praktyk magicznych jako wynikających z mniej lub bardziej spójnej teorii rzeczywistości i uznanie, że rekonstrukcja tej teorii jest niezbędna, by owe praktyki zrozumieć, okazywały się błędem. Koncepcja stojącej za praktyką magiczną „teorii” stanowiła raczej piśmienną projekcję antropologa niż przekonujące narzędzie rozumienia. Słowo magii nie było efektem takiej a nie innej pojęciowej lub przedpojęciowej organizacji doświadczenia. Było swoistym sposobem działania i jako takie należało je badać. Krótko mówiąc, zgodnie z intuicjami Malinowskiego - intuicjami, które nie straciły, moim zdaniem, na aktualności to nasze piśmienne - a dokładnie - tekstowe nachylenie ${ }^{28}$ powoduje, że skłonni jesteśmy postrzegać formuły magiczne jako semantycznie autonomiczne teksty. Nachylenie to powoduje też, że w słowie magicznym widzimy narzędzie myślenia, swoiste, bo podyktowane „magicznym obrazem świata" ${ }^{29}$.

W świetle rozpoznań Malinowskiego przekonanie, że za wszelkimi użyciami słowa magicznego stoi mniej lub bardziej spójna organizacja

${ }^{25}$ Idem, Etnograficzna teoria stowa magicznego, s. 358-359.

${ }^{26}$ Ibidem, s. 359.

${ }^{27}$ L. Lévy-Bruhl, Czynności umystowe $w$ spoteczeństwach pierwotnych, przeł. B. Szwarcman-Czarnota, Warszawa 1992.

${ }^{28}$ Cf. G. Godlewski, Stowo - pismo - sztuka stowa..., s. 235.

${ }^{29}$ Podobną intuicję co do charakteru praktyk magicznych miał później Ludwig Wittgenstein. Choć nie dysponował jakimkolwiek doświadczeniem antropologicznym, a cel jego refleksji nie był zbieżny z celami Malinowskiego, doszedł do zaskakująco podobnych wniosków. Cf. L. Wittgenstein, Uwagi o „Złotej Gatęzi” Frazera, przeł. A. Orzechowski, Warszawa 1998. 
poznawcza, było dyskusyjne. Po pierwsze, zakładało ono dualizm treści doświadczenia oraz języka jako formy ją organizującej. Po drugie, zakładało istnienie zawartej $\mathrm{w}$ umyśle i determinującej magiczne zachowania językowe „struktury głębokiej”. Oba te założenia były podyktowane wspomnianym już „nachyleniem tekstowym” pokutującym do dziś w antropologicznej refleksji nad słowem magicznym. Albowiem to wysoce rozwinięta piśmienność - jak zauważał Roy Harris - tworzy poczucie przepaści między znakiem a denotującym go pojęciem - niematerialna, abstrakcyjną, zdekontekstualizowaną czasowo i przestrzennie treścią, czyniąc tę ostatnią właściwym przedmiotem poznania ${ }^{30}$. Właśnie taki niematerialny i zdekontekstualizowany charakter mają wszelkie, charakterystyczne dla mentalistycznych teorii magii, koncepcje „magicznego obrazu świata” określanego mianem „mistycznych wyobrażeń zbiorowych” czy też „myśli nieoswojonej”’31. Ów obraz świata zostaje w nich wyraźnie odróżniony od użyć słowa magicznego, usytuowanych przestrzennie i czasowo oraz osadzonych w działaniu. A jako systemowy, paradygmatyczny dla wszelkich zachowań językowych, ma być głównym przedmiotem postępowania badawczego.

Demaskacja nachylenia tekstowego sprzyja budowie bardziej otwartych metodologii w badaniach słowa magii. Metodologii, które nie zakładają że funkcja referencyjna jest prymarną funkcją wszelkich, w tym magicznych, praktyk językowych i które nie przyjmuja, że wszelkie użycia słowa magicznego są nieświadomymi artykulacjami ,magicznego obrazu świata". Założenie, jakoby u podłoża wszelkich praktyk magicznych strukturalnie i funkcjonalnie różnorodnych - stał względnie jednolity obraz rzeczywistości, stanowiący artykułowaną nieświadomie przez użytkowników danego języka „magiczną wizję rzeczywistości”, osłabia wrażliwość empiryczną antropologa i powoduje, że kulturowe, medialne i instytucjonalne zróżnicowanie magicznych praktyk językowych zostaje sprowadzone do wspólnego mianownika. Tymczasem słowo magiczne, w zależności od rozmaitych obiegów kulturowych, sytuacyjnych i medialnych, zmienia w radykalny sposób swą specyfikę ${ }^{32}$. Przykładowo, jeśli w kulturach pier-

${ }^{30}$ R. Harris, Racjonalność a umyst piśmienny, przeł. M. Rakoczy (w druku).

${ }^{31}$ Cf. C. Lévi-Strauss, Myśl nieoswojona, przeł. A. Zajączkowski, Warszawa 2001.

${ }^{32}$ Cf. Z. Grębecka, Stowo magiczne poddane technologii. Magia ludowa w praktykach postsowieckiej kultury popularnej, Kraków 2006. 
wotnie oralnych jest ona jedną z podstawowych instytucji kulturowych - rodzajem techniki kulturowej czy też ,wiedzy jak”, to w kulturach zaawansowanej piśmienności staje się ,wiedzą, że”; wiedzą tajemną, zarezerwowaną dla korzystających ze specyficznych tekstów ekspertów ${ }^{33}$. Innymi słowy, zmiana środowiska medialnego i kulturowego radykalnie zmienia słowo magiczne. Teoria Malinowskiego, rzecz jasna, nie pozwalała zmiany tej uchwycić, bo wyrastała z badań nad magią społeczności przedpiśmiennych. Nie pozwalała jednak o zmianie tej zapomnieć, porzucała bowiem przekonanie, że za każdym magicznym użyciem słowa stoi względnie podobny światopogląd.

Oczywiście, także w odniesieniu do oralnych praktyk magicznych miała ona swoje ograniczenia. Polegały one na typowym dla nachylenia tekstowego lekceważeniu dźwiękowego wymiaru formuł magicznych. Owszem, Malinowski - była już o tym mowa - postulował koncentrację na sposobie wykonania magii: $w$ tym na specyficznym sposobie jej intonowania. „Wszelkie zestawy słów języka magicznego wykazują (...) znaczny stopień tajemniczości, odmienności i niezwykłości (...) Większość formuł różni się od potocznych wypowiedzi już samym sposobem ich wyśpiewywania" ${ }^{34}$. Badacz domyślał się, że sam głos, a dokładnie - powiązane z kontekstem pozajęzykowym - złożone sposoby jego modulacji mogą być ważnym elementem znaczącym, którego pismo nie jest w stanie adekwatnie przedstawić, a tym samym - uczynić częścią analizy etnograficznej. Borykając się z problemem zapisu formuł magicznych, zaznaczał obecne $\mathrm{w}$ formułach powtórzenia, a w przypisach do notatek starał się dodać informację o specyfice intonacji, zaznaczając, przykładowo, że czarownik wydaje odgłosy przypominające „czyszczenie gardła”35. Choć zaznaczał, że takie jednostki analityczne, jak ,zdania” i ,słowa” służące segmentacji tego, co mówione, są czymś kulturze oralnej obce, cechują bowiem świadomość językową osób wysoce piśmiennych, to jednak sam się nimi skrupulatnie posługiwał. Dzielił zapisywane formuły na słowa, zdania, wersy oraz zaznaczał ich ,,refreny”. W trakcie tej procedury analitycznej specy-

${ }^{33}$ Cf. M. Buchowski, Magia i rytuat.

${ }^{34}$ B. Malinowski, Etnograficzna teoria słowa magicznego, s. 358-359.

${ }^{35}$ Idem, Fieldnotes, rękopisy znajdujące się w archiwum London School of Economics and Political Science. 
fika intonacji i jej znaczenie - antropologiczne znaczenie głosu jako swoistego i złożonego instrumentu praktyk magicznych - ulegały wyraźnemu przeoczeniu. Dostrzeżenie głosu jako ważnego nośnika znaczeń musiało czekać na kolejne pokolenia etnolingwistów ${ }^{36}$. Również na kolejne pokolenia antropologów, którzy krytykując przemoc widzenia - dominację wzroku jako zmysłu centralnego dla zachodniej kultury nowożytnej - zaczęli dopominać się o badania nad sonosferą innych kultur oraz ich swoistą, niepoddającą się pełnej, wizualnej reprezentacji, semantyką i pragmatyką ${ }^{37}$.

${ }^{36}$ Cf. J. Kawada, Gtos. Studium z etnolingwistyki porównawczej, przeł. R. Nowakowski, Kraków 2005.

${ }^{37}$ Cf. Hearing Culture. Essays on Sound, Listening and Modernity, red. Veit Erlmann, Oxford-New York 2004. 
